Egyptian Journal of Aquatic Biology \& Fisheries

Zoology Department, Faculty of Science,

Ain Shams University, Cairo, Egypt.

ISSN $1110-6131$

Vol. 25(4): 753 - 765 (2021)

www.ejabf.journals.ekb.eg

\title{
Qualitative and Quantitative Study of Dinoflagellate Cysts in Surface Sediments of the Nador Lagoon (North-East Morocco)
}

\author{
Ouassila RIOUCHI ${ }^{*}$, Faid EL MADANI ${ }^{2}$, Ali SKALLI ${ }^{1}$, Mustapha AKODAD ${ }^{1}$, \\ Abdelmajid Moumen ${ }^{1}$ and Mourad BAGHOUR ${ }^{1}$ \\ ${ }^{1}$ OLMAN- BGPE, Nador Multidisciplinary Faculty (FPN), Nador, Mohammed 1st University, \\ Morocco. \\ ${ }^{2}$ INRH-Nador Regional Center, 13 BoulevarZerktouni BP: 493, Nador, Morocco. \\ "CorrespondingAuthor:Ouassila.riouchi@gmail.com
}

\begin{abstract}
ARTICLEINFO
Article History:

Received: June 17, 2021

Accepted: July 28, 2021

Online: Aug. 29, 2021

Keywords:

Nador lagoon,

Dinoflagellate,

Sédiment,

Qualitative,

Quantitative

\section{ABSTRACT}

The qualitative and quantitative study of dinoflagellates (cysts and vegetative forms) was carried out on samples of surface sediments and water of the Nador lagoon (North-East Morocco), collected during winter in February 2019. Therefore, it was necessary to undertake a qualitative and quantitative study on dinoflagellate cysts and vegetative forms in parallel with the aim of specifying the factors that control the concentration of cysts in the sediments, as well as their specific diversities and blooms. Notably, dinoflagellates are of undeniable ecological interest, and are considered as sentinel species of the quantity of water because they respond quickly to environmental changes dueto their very fast life cycle. Moreover, their cysts, due to their extreme resistance and abundance in sediments, constitute an extremely important tool in the evaluation of current environments. Results showed that the total abundances of dinoflagellate cysts vary between a concentration of 720 cysts/g dry sediment (DS) and 7215 cysts/g DS. This work was mainly conducted to study the abiotic parameters of the Nador lagoon that control the concentration of cysts in the sediments, and address their specific diversity and the dominance of one group over the other.
\end{abstract}

\section{INTRODUCTION}

The microalgae account for $45 \%$ of the primary production on earth (Field et al., 1998), and play an important role in regulating the concentration of atmospheric $\mathrm{CO}_{2}$ by sequestering and transporting it to the deep sea. Phytoplankton have both eukaryotic and prokaryotic representatives in the tree of life. Less than 5000 species of marine phytoplankton were formally described in the late 1980s (Sournia et al., 1991; Simon $\boldsymbol{e t}$ al., 2009), and only 80 toxic species and about 200 species harmful to humans and aquatic fauna (Sournia, 1995) were determined. Toxic microalgal blooms are phenomena that have been known since time immemorial and correspond to large and sporadic blooms of toxin-producing microalgae (Belin et al., 2013). Over the past 30 years, the frequency of toxic microalgal blooms appeared to have increased in frequency, intensity, and geographic extent, posing risks to human health and ecosystem components (Zingone \& Enevoldsen, 2000; Hallegraeff, 2003). 
Among the 4000 species of phytoplankton identified in the marine environment (Sournia et al., 1991), approximately300 species are harmful to aquatic organisms while80 species of them are known to produce phycotoxins (Granéli \&Turner, 2006). The dinoflagellates are a group of unicellular eukaryotic phytoplankton with flagella. The most toxic species belong to this group. The toxins produced by these organisms cause different syndromes in humans, such as paralytic shellfish poisoning (PSP), diarrhoeic shellfish poisoning (DSP), diarrhoeic shellfish poisoning (NSP) and amnesic shellfish poisoning (ASP) (Zingone \& Enevoldsen, 2000). The oligotrophic conditions of the Mediterranean Sea favour the proliferation of dinoflagellates; which are typical organisms of nutrient poor waters (Maso \& Garcés, 2006). Some species of dinoflagellates develop forms of resistance (cysts) during a phase of the life cycle (Matantseva $\boldsymbol{e t}$ al., 2020).Derived from a zygote produced during sexual reproduction by gamete fusion (Matsuoka \& Fukuyo, 2000). The coastal lagoons are concerned by the expansion of toxic phytoplankton. These ecosystems are often important shellfish production areas, where the emergence of some potentially toxic dinoflagellate species could threaten aquaculture activities and human health (Azavedo \& Carmouze, 1994).The search for areas at risk of developing toxic dinoflagellates, and the determination of resting cysts belonging to toxic species in these ecosystems allow for better preservation of aquaculture activities. Fartouna and Bellakhal (2016) reported that, the Southern Mediterranean lagoons, such as the lagoons of Nador (Morocco), Bizerte (Tunisia) and Mellah (Algeria) are concerned by recurrent episodes of proliferation of toxic phytoplankton species, particularly dinoflagellates, Alexandrium catenella, Alexandrium minutum, Dinophysis sp., Gymnodinium catenatum and Ostreopsis ovata. These species are responsible for intoxications that can sometimes lead to death and cause serious socio-economic consequences. In Morocco, many studies wereconducted on these dinoflagellate cysts (Hssaida, 1990; Hssaïda \& Morzadec-Kerfourn, 1993; Hssaida et al., 2014; Chekar et al., 2016; Daghor et al., 2016). Thus, the present work was organized to carry out a quantitative and qualitative study of dinoflagellates in the water and surface sediment of the Nador lagoon.

\section{MATERIAL AND METHODS}

\section{Study area}

The lagoon of Nador, also called Sebkha Bou Areg or Mar Chica, is located in the north-east of Morocco on the Mediterranean coast at the level of meridians $2^{\circ} 45^{\prime}-2^{\circ} 55^{\prime}$ $\mathrm{W}$ and parallel $35^{\circ} 10^{\prime} \mathrm{N}$. The lagoon ecosystem of Nador developed in a continental depression oriented NW-SE during the rise of the sea level in the Holocene period (Guillemin \& Houzay, 1982). It represents the second largest lagoon complex in North Africa (115 km² with $25 \mathrm{~km}$ length and $7.5 \mathrm{~km}$ width) and the largest in Morocco. The lagoon communicates with the Mediterranean Sea by a new artificial channel of $300 \mathrm{~min}$ width and $6.5 \mathrm{~min}$ depth. The hydrodynamic circulation in the lagoon is mainly Aeolian (Guelorget et al., 1987; Hilmi, 2005) and the time of water renewal before the construction of the new inlet was estimated to be about 80 days (Hilmi et al., 2005).

The sampling was carried out in the Nador lagoon in February 2019 at nine stations distributed in a way to ensure a wide spatial coverage of the lagoon (Fig.1). 


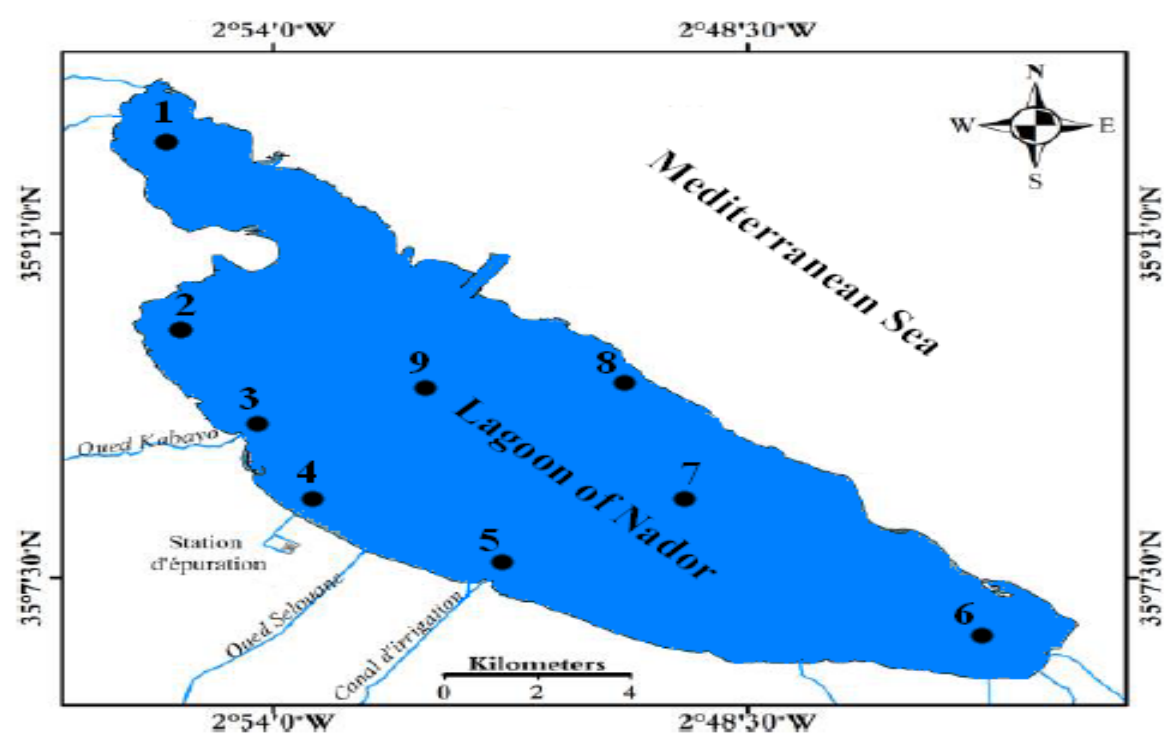

Fig. 1: The distribution of sampling stations

Station 1 corresponds to Beniansar (W $002^{\circ} 55,460$; N 35 15,148 ), Station 2 corresponds to Tirakae (W002 $2^{\circ} 5,522$; N35 11,772 ), Station 3 corresponds to Oued caballo (W002 54,$325 ; \mathrm{N} 35^{\circ} 09,820$ ), Station 4 corresponds to the sewage treatment plant (W002 53,383 ; N35 08,299), Station 5 corresponds to Oued Bou Areg (W002 51,443 ; N35 07,549), Station 6 corresponds to Kariat Arakman (W002 45,167 ; $\mathrm{N} 35^{\circ} 06,401$ ), Station 7 is at the center lagoon side Arekmane (W002 ${ }^{\circ} 48,884$; N35 08,236 ), Station 8 is between the old pass and Mohandis (W002 49,802 ; N35 10,465 ), Station 9 is the lagoon center (W002 52,517 ; N35 11,012 ) (Fig. 1).

The Dinoflagellates and cysts in the surface sediments were studied qualitatively and quantitatively. The sampling of sediments and phytoplankton were carried out in parallel with the measurements of the (In-situ and Ex-situ) physicochemical parameters of the lagoon water at the nine sampling sites.

\section{Sampling Strategy}

At each station, the sampling of surface sediments of the lagoon of Nadoris was done using cylindrical cores ( $80 \mathrm{~cm}$ long, $8 \mathrm{~cm}$ in diameter) operated by a professional diver. Only the top $3 \mathrm{~cm}$ of surface sediments were taken, then stored in total darkness at $4{ }^{\circ} \mathrm{C}$ until analysis. The cysts weremainly distributed in the first three centimetres of the sediment surface (Erard $\boldsymbol{e t}$ al., 1993). The sampled sediment was used for analysis of water content, total organic carbon and total inorganic carbon. Cysts from the sediment were separated by the modified density gradient method using Ludox CLX described by Erard et al.(1995), Yamaguchi et al.(1995) and Genovesi et al.(2007). Once the extraction operation was completed, the dinocysts werestored in aluminumcovered tubes, and then placed at $4^{\circ} \mathrm{C}$ to wait the counting and identification phase, using an inverted light microscope.

The identification of dinocystsis based on morphological characteristics was determined using identification keys and plates illustrated in articles and publications dealing with dinocysts (Head, 1996; Zonneveld 1997a, 1997b; Zonneveld \& Jurkschat, 1999; Rochonet al., 1999; Head et al., 2001; Pospelova \& Head, 2002; Kim et al., 2007; Matsuoka et al., 2009; Draredja et al., 2020). 
The observation of the different species of cysts of the Nador lagoon was carried out with an inverted microscope "Leica DM750", with a magnification of 40x. For each sample, $1 \mathrm{ml}$ was taken and distributed on a Sedgewick counting plate allowing the counting of dinocysts under the inverted microscope. The calculation of the abundance of dinocysts in each sample allows determining the number of cysts at rest per gram of wet sediment. In parallel with a study of the water content, organic and inorganic carbon of the sediment and a study of the organic matter content.

On the other hand, the analysis of physicochemical parameters of the water of the Nador lagoon for each sampling station was adjusted with in situ measurements (temperature, $\mathrm{pH}$, salinity, conductivity, dissolved oxygen and turbidity) the help of the specific probe and the analysis of nutrients (nitrogen and phosphorus), as well as the analysis of biological parameter (Chl-a)

The physico-chemical analysis of the water was carried out at the INRH-Nador laboratory, whereas the analysis of the sediments was performed at the OLMAN- BGPE laboratory. Additionally, the study of cysts was achieved at IFREMER- France (Sète).

The temperature and salinity were obtained respectively using an ORION STAR A122. The $\mathrm{pH}$ measurements were recorded using a $\mathrm{pH}$ meter IONOMETER-EUTECHINSTRUMENTS-CYBERSCAN-PH-510, and the turbidity of the seawater was measured in situ with a turbid meter (EUTECH TN-100 instrument). For the analysis of nutrients (nitrates, nitrites and phosphates), the methods used weredescribed in the manual of chemical analysis in the marine environment (Aminot \& Chaussepied, 1983; Aminot \& Kérouel, 2004). The Chlorophyll (a) and the suspended solids were determined by the $0.45 \mu \mathrm{m}$ membrane filtration method.

On the other hand, the determination of the organic matter wasobtained by incineration of the samples (loss of weight in fire or loss by calcination) (CEAEQ, 2003). The percentage of organic matter wascalculated following the successive equation:

$\%$ O.M. = dry sample weight $(\mathrm{g})$ - incinerated sample weight $(\mathrm{g}) /$ dry sample weight

(g)*100.

The total inorganic carbon (TIC) wasdeduced from the loss ofignition at $950^{\circ} \mathrm{C}$ according to the following relationship:

Law $950=(\text { mass B }- \text { mass C/mass B })^{*} 100$, With CIT $=$ Law 950*0.273.

\section{RESULTS AND DISCUSSION}

\section{Pysicochemical parameters}

The average water temperature of the Nador lagoon in the nine stations (February 2019) was $17.25^{\circ} \mathrm{C}$ (Table 1), with a maximum of $18.4^{\circ} \mathrm{C}$ recorded at station 4 of a depth of $0.6 \mathrm{~m}$. While, a minimum of $16^{\circ} \mathrm{C}$ was recorded in station 3 which corresponds to Oued Caballo with a depth of $0.70 \mathrm{~m}$. The average $\mathrm{pH}$ value was7.8 with a maximum value of 8 recorded in station 1, which corresponds to Beni Ansar with a depth of $8 \mathrm{~m}$. A minimum value of 7.6 was recorded in station 3 that corresponds to Oued Caballo of $0.70 \mathrm{~m}$ depth (Table 1). In relation to salinity, the highest value was $38.8 \%$ o detected in station 1, whilethe lowest was in station 3 (33.1\%) (Table 1). Electrical conductivity (EC) is another parameter used for water quality monitoring (Pal et al., 2015). The lowest and the highest values of electrical conductivity were recorded respectively at the sites $3(51.8 \mathrm{mS} / \mathrm{cm})$ and $1(57.9 \mathrm{mS} / \mathrm{cm})$ (Table 1). Concerning the average turbidity of 
the water of the lagoon, it was 0.86 NTU oscillated between a null value observed at station 1 and a maximum of 2.34 NTU recorded at station 3(Table 1). While the minimum and the maximum dissolved oxygen measured at the lagoon of Nador were respectively $9.37 \mathrm{mg} / \mathrm{l}$ at station 4 which corresponds to the treatment plant with depth of $0.60 \mathrm{~m}$, and of $12.6 \mathrm{mg} / \mathrm{l}$ at station 2 which corresponds to Tirakae with a depth of $0.40 \mathrm{~m}$. These values are comparable with the one found by El Madani (2012) and Mostareh (2018).

Table 1: The in-situ physicochemical parameters of the Nador lagoon (February 2019)

\begin{tabular}{ccccccc}
\hline Stations & $\begin{array}{c}\text { Temperature } \\
\left({ }^{\circ} \mathrm{C}\right)\end{array}$ & Salinity & $\mathrm{pH}$ & $\begin{array}{c}\text { Conductivity } \\
(\mathrm{mS} / \mathrm{cm})\end{array}$ & $\begin{array}{c}\text { Turbidity } \\
(\mathrm{NTU})\end{array}$ & $\begin{array}{c}\text { Dissolved } \\
\text { Oxygen } \\
(\mathrm{mg} / \mathrm{l})\end{array}$ \\
\hline St1 & 17.30 & 38.80 & 8.00 & 57.90 & 0.00 & 10.37 \\
\hline St2 & 17.50 & 37.80 & 7.94 & 56.30 & 0.31 & 12.60 \\
\hline St3 & 16.00 & 33.10 & 7.60 & 51.80 & 2.34 & 7.99 \\
\hline St4 & 18.40 & 37.40 & 7.70 & 56.80 & 1.71 & 7.34 \\
\hline St5 & 17.60 & 37.30 & 7.71 & 56.60 & 1.01 & 7.50 \\
\hline St6 & 17.00 & 37.10 & 7.92 & 56.40 & 0.69 & 9.47 \\
\hline St7 & 17.00 & 37.50 & 7.83 & 56.80 & 0.58 & 9.50 \\
\hline St8 & 16.60 & 35.90 & 7.86 & 57.30 & 0.63 & 9.46 \\
\hline St9 & 17.85 & 37.40 & 7.94 & 56.80 & 0.46 & 10.10 \\
\hline
\end{tabular}

The distribution of the suspended solid contents during the period of this study (Table 2) shows that the highest value of $0.036 \mathrm{mg} / 1$ was recorded in the site 6 which corresponds to Kariat Arakman with a depth of $1.48 \mathrm{~m}$. However, the minimum value was recorded at station $7(0.022 \mathrm{mg} / \mathrm{l})$. Chlorophyll-a contents varied between a zero value at station 1 (Table 2), and a maximum value of $0.267 \mu \mathrm{g} / 1$ at station 9 , with an average of $0.13 \mu \mathrm{g} / \mathrm{l}$. The concentrations of orthophosphates varied between a minimum value of $0.090 \mathrm{mg} / \mathrm{l}$ recorded at the station 9 (Table 2), and a maximum of $0.235 \mathrm{mg} / \mathrm{l}$ recorded at the station 4 , which is near the wastewater treatment plant (WWTP). This WWTP rejected its effluents after treatment which is characterized by their high phosphate content. Regarding the nitrate content in the water of the Nador (Table 2), results showed that the average value of this nutrient during February 2019 was $0.375 \mathrm{mg} / \mathrm{l}$, with a maximum of $0.743 \mathrm{mg} / \mathrm{l}$ recorded at station 1 , while the minimum was found at station $8(0.007 \mathrm{mg} / \mathrm{l})$, which is characterized by a depth of $7.86 \mathrm{~m}$. The maximum value of nitrite was $0.150 \mathrm{mg} / \mathrm{l}$ recorded at station 3 , while the minimum value was $0.009 \mathrm{mg} / 1$ detected at station 8 , with an average of $0.079 \mathrm{mg} / \mathrm{l}$ (Table 2).

Table 2: Ex-situ physicochemical parameters of the Nador lagoon (February 2019)

\begin{tabular}{cccccc}
\hline Stations & $\begin{array}{c}\text { Suspended solids } \\
(\mathbf{m g} / \mathbf{l})\end{array}$ & $\begin{array}{c}\mathbf{N O}_{\mathbf{2}} \\
(\mathbf{m g} / \mathbf{l})\end{array}$ & $\begin{array}{c}\mathbf{N O}_{\mathbf{3}} \\
(\mathbf{m g} / \mathbf{l})\end{array}$ & $\begin{array}{c}\mathbf{P O}_{\mathbf{4}} \\
(\mathbf{m g} / \mathbf{l})\end{array}$ & $\begin{array}{c}\mathbf{C h l}(\mathbf{a}) \\
(\boldsymbol{\mu g} / \mathbf{l})\end{array}$ \\
\hline St1 & 0.026 & 0.024 & 0.743 & 0.145 & 0 \\
\hline St2 & 0.028 & 0.028 & 0.034 & 0.120 & 0.106 \\
\hline St3 & 0.028 & 0.150 & 0.399 & 0.220 & 0.160 \\
\hline St4 & 0.033 & 0.028 & 0.192 & 0.235 & 0.106 \\
\hline St5 & 0.029 & 0.027 & 0.054 & 0.190 & 0.053 \\
\hline St6 & 0.036 & 0.025 & 0.049 & 0.110 & 0.053 \\
\hline St7 & 0.022 & 0.020 & 0.064 & 0.135 & 0.053 \\
\hline St8 & 0.026 & 0.009 & 0.007 & 0.100 & 0.106 \\
\hline St9 & 0.027 & 0.015 & 0.019 & 0.090 & 0.267 \\
\hline
\end{tabular}




\section{Sedimentological analysis and distribution and abundance of dinoflagellate cysts}

Table (3) shows that the maximum value of organic matter (OM) reached a value of $51.64 \%$ at station 9 and a minimum value of $23.87 \%$ at station 2 . While, the maximum value of total organic carbon(TOC) reaches a value of $25.82 \%$ at station 9 and a minimum value of $11.93 \%$ at station 2 . While, the maximum value of the total inorganic carbon (TIC) was6.91\%(station 8), whereas the minimum value was $1.34 \%$ (station 3). These results suggest that the high content of the total organic carbon in sediment is associated with the predominantly smectite clay faces of the deeper central zones (El-Alami et al., 1998). The valuesrecorded during the present work are relatively high compared to those previously found in Mar Chica (El-Alamiet al.,1998). Likewise, when compared to results other lagoon systems (Tesson, 1982; Lakhdar, 1987). On the other hand, the currentresults showed high rate of organic matter in all samples, especially those collected from the centre of the lagoon. These results are in agreement with those of Abouhala $\boldsymbol{e t}$ al. (1995) and Lefebvre et al.(1997) .Remarkably, the identification of dinoflagellate's cysts is done according to morphological characteristics with the use of an inverted light microscope. Many species of cysts such as cysts with a brown, black, or grey colour are very difficult to identify because of their similarity adding to their dark colour that makes it difficult to distinguish either the internal parts (red bodies ...) or theexternal parts (ornaments...).The lagoon of Nador presents a relatively important diversity of cysts with 64 different morphotypes.

In the present work, only 16 species were identified because it is very hard to identify the exact species from the cyst. In the present work and at 9 sampled stations, the main cysts dominated were Alexandrium minutum, Scripsiella ramonii, Polykrikos schwartzii, Polykrikos kofoidii, and Operculodinium israelainum, with heterogeneous abundances and uneven distribution. The maximum density of cysts in the lagoon of Nador reached $7215 \mathrm{cysts} / \mathrm{g}$ at station 6 , and a minimum density of $720 \mathrm{cysts} / \mathrm{g}$ was detected at station3 (Table 3). The cyst with the highest cumulative density was Alexandrium minutum with a value of about 3045 cysts/g observed at station 6 . This was followed by a density of 1710 cysts/g of Scripsiella ramonii observed at station 5 . Eminently, the densities of cysts found varied between 720 and7215 cysts/g), which are higher than those found in the Mediterranean coastal waters such as those of the Mellah lagoon in Algeria recording a maximum density of 315 cysts/g (Draredja et al., 2020). Moreover, the present recorded densities were also higher than those of Ghar El Melahin lagoon in Tunisia, determining a density of 229 cysts/g (Dhib et al., 2016). Compared to the results of Homa lagoon (Tukey) with a density of cysts reaching71 cysts/g (Aydin et al., 2014); and the density found in Cabras lagoon in Sardinia, Italy with a density of 287 cysts/g (Satta et al.,2014), the current values are also higher. 
Table3: Geographical coordinates of the sampling stations in the Nador lagoon, with total number of resting cysts (Total RCs counts), organic matter (OM), total organic carbon (TOC), total inorganic carbon (TIC), and water content (WC).

\begin{tabular}{cllccc}
\hline Station & Geographic Coordinates & $\begin{array}{l}\text { OM } \\
(\%)\end{array}$ & $\begin{array}{c}\text { TOC } \\
(\%)\end{array}$ & $\begin{array}{l}\text { TIC } \\
(\%)\end{array}$ & $\begin{array}{c}\text { Total RCs counts } \\
\text { (cysts/g) }\end{array}$ \\
\hline St1 & $\mathrm{N} 35^{\circ} 15.14-\mathrm{W} 002^{\circ} 55.46$ & 32.19 & 16.09 & 4.63 & 3750 \\
\hline $\mathrm{St} 2$ & $\mathrm{~N} 35^{\circ} 11.77-\mathrm{W} 002^{\circ} 55.52$ & 23.87 & 11.93 & 1.62 & 1530 \\
\hline $\mathrm{St} 3$ & $\mathrm{~N} 35^{\circ} 09.82-\mathrm{W} 002^{\circ} 54.32$ & 23.95 & 11.97 & 1.33 & 720 \\
\hline $\mathrm{St} 4$ & $\mathrm{~N} 35^{\circ} 08.29-\mathrm{W} 002^{\circ} 53.38$ & 28.63 & 14.31 & 4.33 & 2205 \\
\hline $\mathrm{St} 5$ & $\mathrm{~N} 35^{\circ} 07.36-\mathrm{W} 002^{\circ} 51.44$ & 24.94 & 12.47 & 2.81 & 6795 \\
\hline $\mathrm{St} 6$ & $\mathrm{~N} 35^{\circ} 06.40-\mathrm{W} 002^{\circ} 45.16$ & 44.46 & 22.23 & 4.50 & 7215 \\
\hline $\mathrm{St} 7$ & $\mathrm{~N} 35^{\circ} 08.23-\mathrm{W} 002^{\circ} 48.88$ & 48.88 & 24.44 & 4.51 & 6390 \\
\hline $\mathrm{St} 8$ & $\mathrm{~N} 35^{\circ} 10.46-\mathrm{W} 002^{\circ} 49.80$ & 32.65 & 16.32 & 6.91 & 3240 \\
\hline $\mathrm{St} 9$ & $\mathrm{~N} 35^{\circ} 11.01-\mathrm{W} 002^{\circ} 52.51$ & 51.64 & 25.82 & 4.45 & 2670 \\
\hline
\end{tabular}

\subsection{Abiotic parameters: Sediment water content}

To determine the abundance of cysts per gram of dry sediment, the water content percentage of the sediment was measured. Moreover, the water content of the sediment sampled in the different stations of the Nador lagoon wasbetween $22.09 \%$ at station 2 which corresponds to Tirakae and $49.49 \%$ at station 9, with an average of $35.79 \%$. Meanwhile, stations 2, 3, 4 and 5 presented the lowest water content with contents between $22.09 \%$ and $27.40 \%$ in water. While, stations $1,6,7$ and 9 recordedthe highest water content with values ranging from $32.50 \%$ to $49.50 \%$ andan average value of $33.33 \%$ (Fig.2).The sediments of the Nador lagoon studied hadquite high natural moisture content. Water contents were between 22.09 and $49.50 \%$, these variations in natural water content may be related to the amount of fine elements in the analysed samples. Therefore, the values of water content are found significant in all samples, which explains the hygroscopic character and the high value of porosity (Rollet \& Bouaziz, 1972).

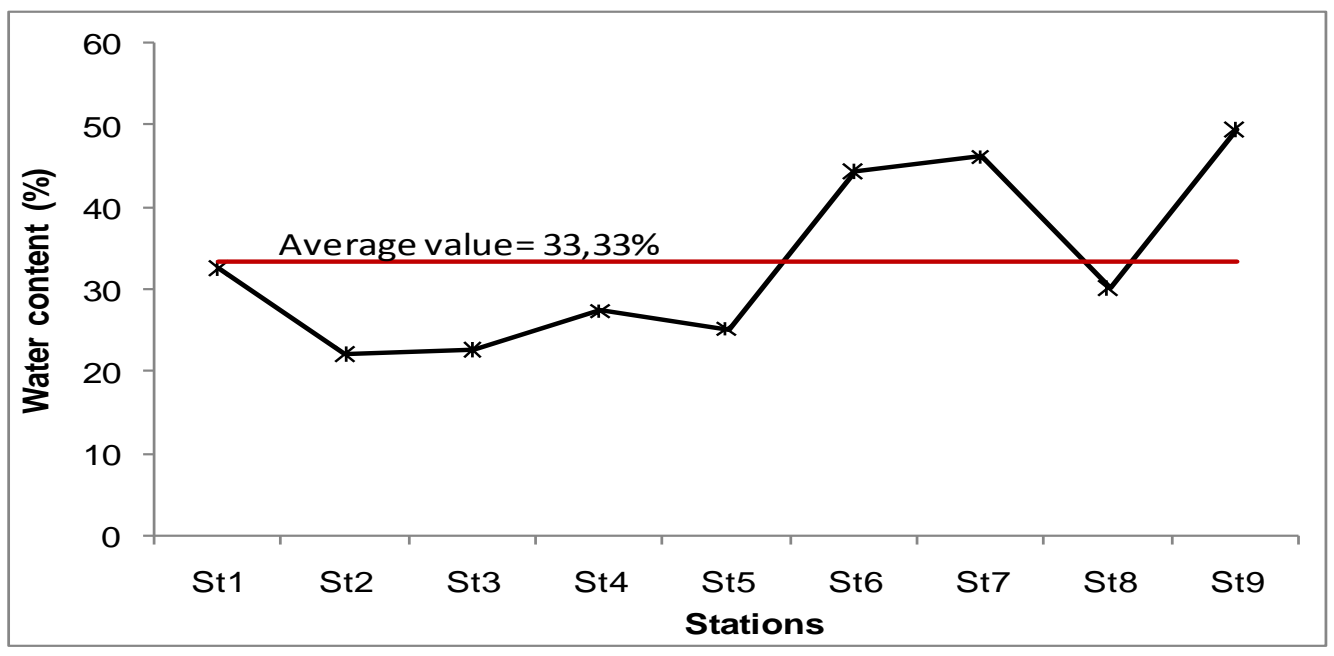

Fig.2: Water content of the sediments in Nador Lagoon 


\section{Statistical analysis}

\subsection{Relationship between environmental factors and resting cysts abundance}

The multivariate analysis (PCA) shows that the first two factorial axes provide nearly $60.20 \%$ of the information (Fig. 3). The F1 axis explains $44.09 \%$ of the total variation, it is constructed mainly by the positive correlation between the variables; water content, total organic carbon(COT), total inorganic carbon (CIT), abundance, temperature, salinity, $\mathrm{pH}$, dissolved oxygen (DO) and depth; and negatively with the variables $\mathrm{Chl}(\mathrm{a})$, turbidity, $\mathrm{NO}_{2}, \mathrm{MES}, \mathrm{PO}_{4}$ and $\mathrm{NO}_{3}$. On the other hand, the $\mathrm{F} 2$ axis explains $16.11 \%$ of the total variation, it is constructed mainly by the positive correlations of the variables; water content, total organic carbon (COT), total inorganic carbon (CIT), abundance, $\mathrm{Chl}(\mathrm{a})$, turbidity, $\mathrm{NO}_{2}$ and MES; and the negative correlation of the variables temperature, salinity, $\mathrm{pH}$, dissolved Oxygen (D.O), depth, $\mathrm{NO}_{3}$ and $\mathrm{PO}_{4}$.

This multivariate analysis (PCA) indicates that the abundance of dinocysts is significantly correlated with the aforementioned environmental factors of the sediment surface (Fig. 3), such as water content, total organic carbon (COT), and total inorganic carbon (CIT).

Fig. (4)shows that a linear relationship between organic matter and cyst abundance is spotted. It is also observed that with increasing organic matter the abundance of cysts increases, except for the two stations of St5 and St9.

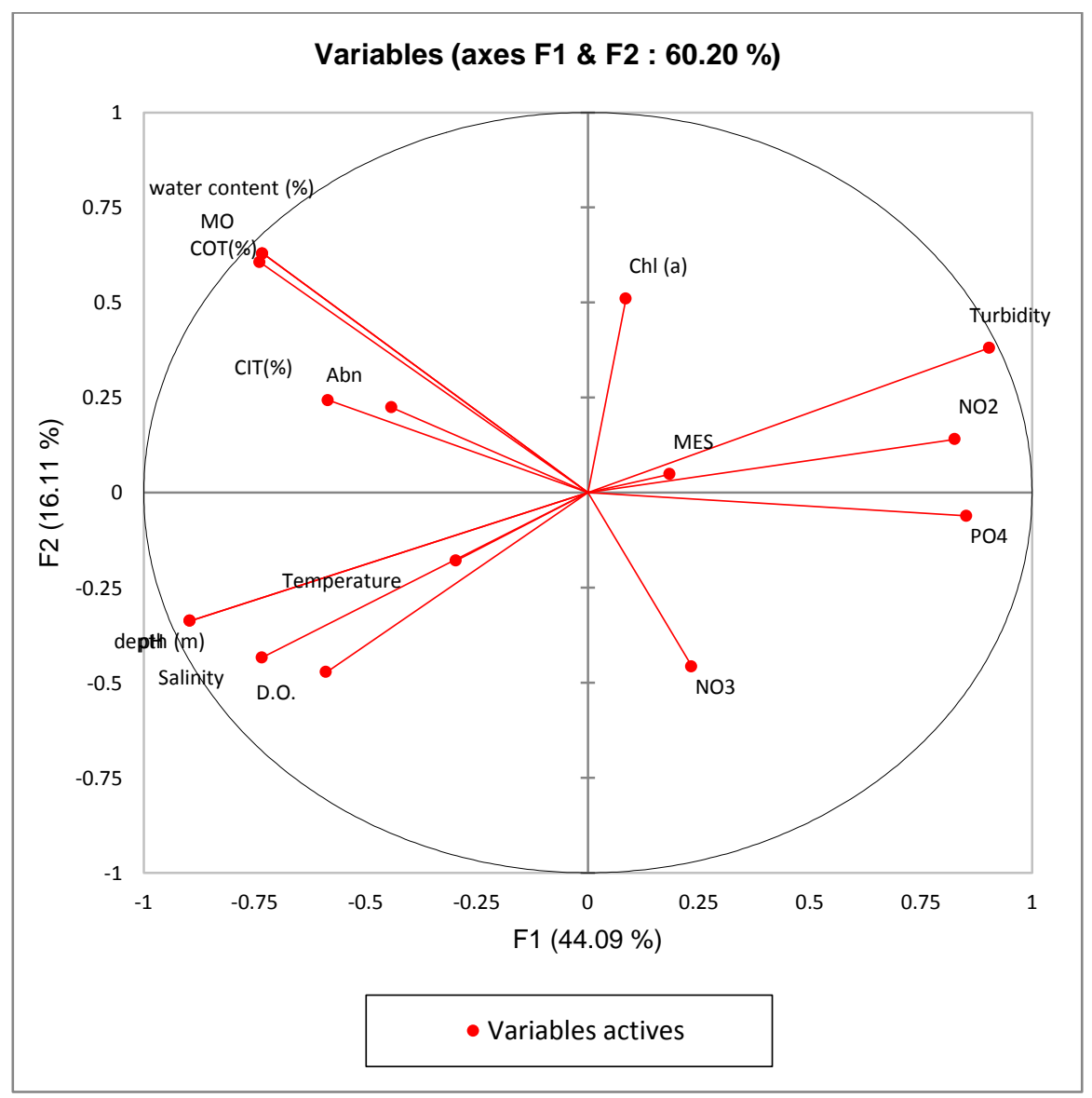

Fig.4. Principal component analysis (PCA) for dinocyst density (TRC count) related to environmental factors ( $\mathrm{T}$ : temperature, Sal: salinity, DO: dissolved oxygen, $\mathrm{pH}$, Cond: Conductivity, Turbidity, MES, $\mathrm{NO}_{2}, \mathrm{NO}_{3}, \mathrm{Chl}(\mathrm{a}), \mathrm{PO}_{4}, \mathrm{WC}$ : water content, $\mathrm{OM}$ : organic matter, COT: total organic carbon, CIT: total inorganic carbon (axes F1 and F2 $=60.20 \%)$. 


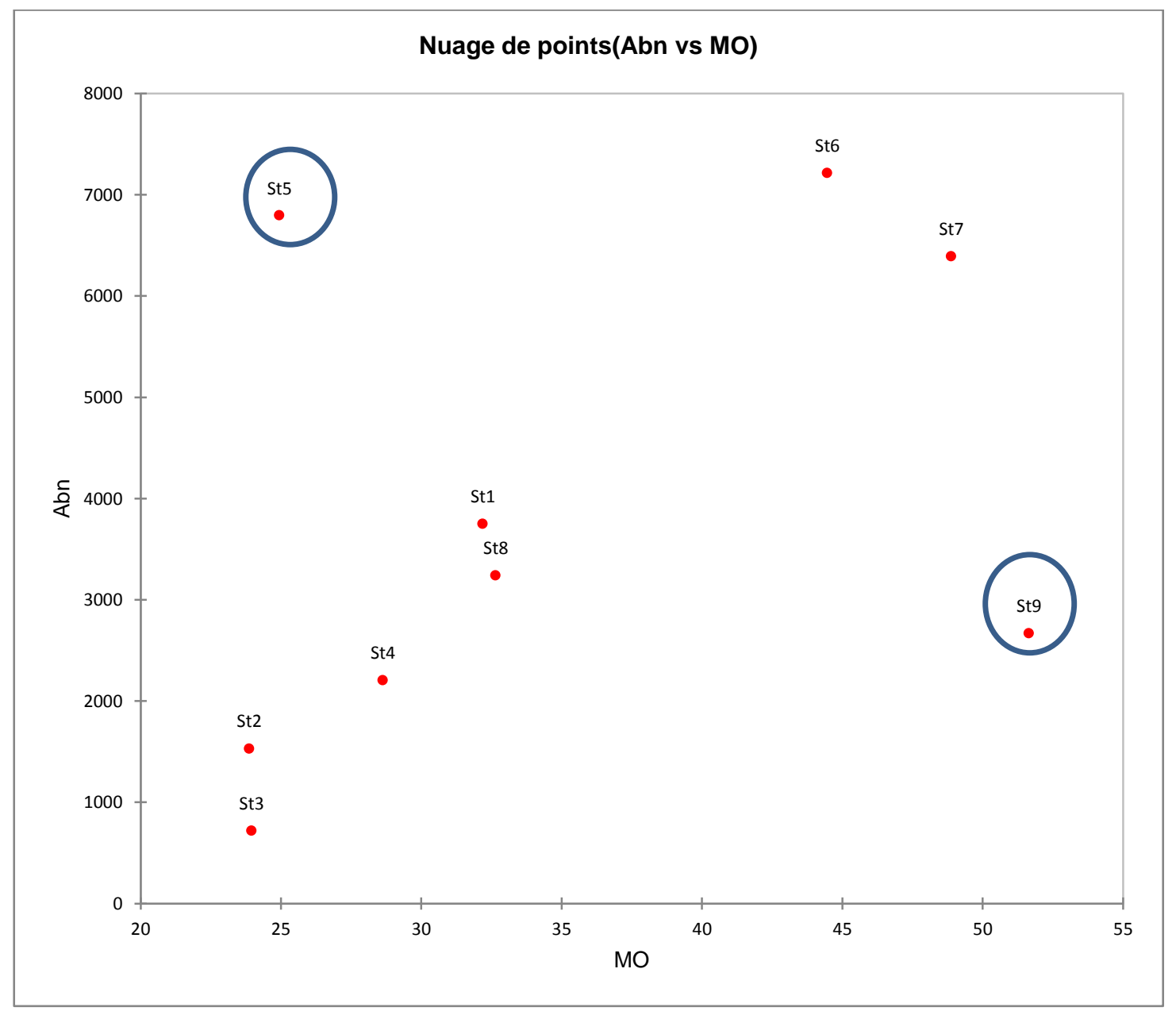

Fig.5.Scatter plot (Abandonment of dinocysts as a function of organic matter)

\section{CONCLUSION}

The qualitative and quantitative analysis of dinoflagellate cysts of the Nador lagoon was conducted at nine stations. Results revealed that the total abundance of dinoflagellate cysts varied between a concentration of 720 cysts/g dry sediment (DS) and 7215 cysts/g DS. Quantitatively, the total values of dinoflagellate cysts of the Nador lagoon observed in February 2019 showed that, the highest value was6795 cysts/g DS atOued BouArg site, 7215 cysts/g at Kariat Arakma and 6390 cysts/g DS in the centre of the lagoon of Nador, characterized by a depth of 7.83 meters. It is worth noting that, the main dominant cysts wereAlexandrium minutum, Scripsiella ramonii, Polykrikos schwartzii/kofoidii, Operculodinium israelainum, with heterogeneous abundances and uneven distribution. 


\section{REFERENCES}

Abouhala, A.; Boukabous, R.; Dafir, J. E. and Talbaoui, E. (1995).Caractérisation physicochimique de la lagune de Nador. Rev.Maroc.Sci.Agro.Vétéri, 15(4): 43-52.

Aminot, A. and Marcel, C. (1983). Manuel des analyses chimiques en milieu marin, Brest, France

Aminot, A.; Kérouel, R. and Mauvais, J.L. (1986).Les éléments nutritifs en baie de Seine. La Baie de Seine, Ifremer,actes de colloques, 4:289-295.

Aydin, H.; Yürür, E. E. andUza,S.(2014).Dinoflagellate cyst assemblages in surface sediments from Homa Lagoon (Izmir Bay, Eastern Aegean Sea, the Mediterranean). Fres. Envi.Bull 23(8): 1795-1801

Belin, C.; Annie,C.; Daniel, D.; Elisabeth, N.and Raffaele,S.(2013). Dynapse-dynamiques des efflorescences et de la toxicité des espèces phytoplanctoniques nuisibles du genre pseudo nitzschiaen région Loire Bretagne.Ifremer Report, France.

Bloundi,M.K.(2005). Etudes géochimique de la lagune de Nador (Maroc oriental) : impacts des facteurs anthropiques. Ph.D. Thesis, University Mohammed V, Fac. Sci. Rabat, Morocco and ULP-EOST Strasbourg I, France.

Center of Expertise in Environmental Analysis and Ministry of Agriculture and Fisheries for Food of Quebec, (CEAEQ) (2003). Determination of organic matter by determination of organic carbon in agricultural soils by method of Walkley-Black's modified method, MA. 1010 -WB 1.0, Ministry of Environment of Quebec, p.10.

Chekar, M.; Hamid,S.; Koré,G.; Habiba, A. and Lahcen, A.(2016). «Biostratigraphie des kystes de dinoflagellés et paléoenvironnements dans l'Eocène de la coupe d'Ibn Batouta, région de Tanger, Rif Externe occidental, Maroc ». pp. 79-93 in Annales de Paléontologie, vol. 102. Elsevier

Daghor,L.; Touria, H.; Naima, H.; Sara, C.; Btissam, E.; Mohamed, F. and Keltoum, EL.B.(2016). Etude des kystes de dinoflagellés des sédiments de surface du système lagunaire atlantique marocain Oualidia-Sidi Moussa et de la lagune méditerranéenne de Nador ». Bull. 1'Institut Sci. Rabat, Sect. Sci. la Terre 38:1-18.

Dhib, A.; Fertouna, B.; Turky,S. and Aleya, L.(2016). Driving factors of dinoflagellate cyst distribution in surface sediments of a Mediterranean lagoon with limited access to the sea. Mar.Pollut.Bull.,112(1-2): 303-312.

Draredja, M.A.; Frihi, H.; Boualleg, C.; Abadie, E. and Laabir, M. (2020). Distribution of dinoflagellate cysts assemblages in recent sediments from a southern Mediterranean lagoon (Mellah, Algeria) with emphasis on toxic species. Environ. Sci. Pollut. Res. 27: 2517325185.

El-Alami, M.; Mahjoubi, R.; Damnati, B.; Kamel, S.; Icole, M. and Taieb, M. (1998).Sédimentologie et géochimie organique des sédiments superficiels de la lagune de Nador (Maroc nord-oriental). J. Af. E. Sci, 26(2): 249-259.

El Madani, F. (2012). Caractérisation écologique de l'écosystème lagunaire de Nador sur la base de son peuplement phytoplanctonique. Ph.D. Thesis, Faculty of Science, Mohammed First University, Morocco. 
Erard, L.D.E. and Boulay, V. (1995). Resting cysts of Alexandrium minutum in marine sediments: quantification by three methods. Harmful Marine Algal Blooms. Lavoisier Publishing, Paris.

Erard,L.D.E.; Desbruyeres, E. and Olu K. (1993).Alexandrium minutum: Resting cyst distribution in the sediments collected along the Brittany coast. In: "Toxic phytoplankton blooms in the sea." Smayda, T.J. \& Shimizu, Y. (Eds.). Elsevier, Amesterdam, pp. 109114.

Fartouna, B.M. (2016). Distribution spatiale des kystes de résistance des Dinoflagellés au niveau du sédiment superficiel de la lagune de Bizerte: cas de l'espèce invasive Alexandrium pacificum RW Litaker, 2014. Ph.D. Thesis, Université de Franche-Comité, Université de Carthage, Tunisie.

Field,C.; Michael, J.B.; James,T.R. and Paul, F. (1998). Primary production of the biosphere: integrating terrestrial and oceanic components. Science 281(5374):237-40.

Genovesi, B.; Mouillot, D.; Vaquer,A.; Laabir, M. and Annie, P. (2007). Towards an optimal sampling strategy for Alexandrium catenella (Dinophyceae) benthic resting cysts. Harmful Algae 6(6):837-48.

Granéli, E. and Jefferson T.T. (2006). Ecology of Harmful Algae, First ed. Springer, Berlin, Heidelberg.

Guelorget, O.; Perthuisot, J.P.; Frisoni, G.F.and Monti, D. (1987). Le rôle du confinement dans l'organisation biogéologique de la lagune de Nador (Maroc). Oceanologica Acta, 10(4): 435-444.

Guillemin, M. and Houzay, J.P. (1982).Etudes géologiques sur la Chaîne du Rif. III: Le Néogène post-nappes et le Quaternaire du Rif nord-oriental. Stratigraphie et tectonique des bassins de Mellila, du Kert, de Boudinar et du piedmont des Kebdana. Notes du service géologique du Maroc, (314):7-238.

Hallegraeff, G. M. (2003). Harmful algal blooms: a global overview. Manual on harmful marine microalgae 33:1-22.

Head, M.J.(1996). Modern dinoflagellate cysts and their biological affinities. Palynology: principles and applications 3:1197-1248.

Head, M. J.; Harland, R. and Matthiessen, J. (2001). Cold marine indicators of the late Quaternary: the new dinoflagellate cyst genus Islandinium and related morphotypes. Journal of Quaternary Science: Published for the Quaternary Research Association 16(7):621-36.

Hilmi, K.; Orbi, A.; Lakhdar, J.I. and Sarf, F.(2005). Etude courantologique de la lagune de Oualidia (Maroc) en automne. Bull. Inst. Sci. 26-27: 67-71

Hssaida, T. (1990). Etude palynologique: kystes de dinoflagelles du jurassique (bathonien, callovien, oxfordien) du bassin de guercif (maroc). Ph.D. Thesis, Université Renne 1, France.

Hssaida, T.; Soumia, C.;Mohamed ,B.; James, B.R.and Fatima,O. (2014).Associations de kystes de dinoflagellés des séries du Jurassique supérieur (Oxfordien-Tithonien) du Rif externe (Prérif interne et Mésorif, Maroc) et comparaisons régionales. Ann. Paleontol. 100(4):372-342.

Hssaïda, T. and Marie,T.M.K. (1993). Kystes de dinoflagellés et palynofaciès: indicateurs des variations bathymétriques dans le bassin de Guercif (Maroc) au Jurassique (bathonien 
terminal-Oxfordien basal). Rev.pal. Palyno. 77(1-2):97-106.

Kim, C.J.;Hak,G.K.;Chang, H.K. and Hee,M.O. (2007). Life cycle of the ichthyotoxic dinoflagellate Cochlodinium polykrikoides in Korean coastal waters. Harmful algae 6(1):104-11.

Lakhdar, R. (1987). Contribution à l'étude sédimentologique et géochimique des sédiments superficiels de la Sabkha Boujmel (sud-est de la Tunisie). M. Sc.Thesis,Fac of Sci. Tunis.

Lefebvre, A.;Guelorget, O.; Perthuisot, J. P. and Dafir, J. E. (1997).Évolution biologique de la lagune de Nador (Maroc) au cours de la période 1982-1993. Oceanolica Acta, 20(2): 371-385.

Maso, M.and Esther, G. (2006). Harmful microalgae blooms (HAB); problematic and conditions that induce them. Marine pollution bulletin. 53(10-12):620-30.

Matantseva, O.; Berdieva, M.; Kalinina, V.; Pozdnyakov,I.;Pechkovskaya, S.and Skarlato, S. (2020). Stressor-induced ecdysis and thecate cyst formation in the armoured dinoflagellates Prorocentrumcordatum. Sci Rep 10: 18322.

Matsuoka, K. and Fukuyo,Y. (2000). Technical Guide For Modern Dinoflagellate Cyst Study ». WESTPAC-HAB, Japan Society For The Promotion Of Science, Tokyo, Japan.

Matsuoka, K.; Hisae,K.; Satoshi,N.; Mitsunori,I. and Haruyoshi,T. (2009). Re-examination of cyst-motile relationships of Polykrikos kofoidii Chatton and Polykrikos schwartzii Bütschli (Gymnodiniales, Dinophyceae). Review of Palaeobotany and Palynology 154(14):79-90.

Mostareh, M.(2018).Impact de l'ouverture de la nouvelle passe de la lagune de Nador sur l'organisation spatiotemporelle du peuplement phytoplanctonique.Ph.D. Thesis, Faculty of Sciences. Biology Department, Mohammed 1 University, Morocco.

Oliveira, A.S.M.F. and Jean-Pierre,C. (1994). Une mortalité de poissons dans une lagune tropicale (Brésil) durant une période de dominance de cyanophyceae: Coincidence ou conséquence. Revue d'hydrobiologie tropicale 27(3):265-72.

Pal, M.; Samal, N.R.; Roy,P. K. and Roy, M.B. (2015). Electrical conductivity of lake water as environmental monitoring - A case study of Rudrasagar lake. IOSR Journal Of Environmental Science, Toxicology And Food Technology. 9(3): 66-71.

Pospelova, V. and Martin, J. H. (2002).Islandinium brevispinosum sp. nov.(Dinoflagellata), a new organic-walled dinoflagellate cyst from modern estuarine sediments of New England (USA). Journal of Phycology 38(3):593-601.

Rochon, A.; Vernal, A.; Turon, J.L.; Jens,M. and Martin J.H. (1999). Distribution of recent dinoflagellate cysts in surface sediments from the North Atlantic Ocean and adjacent seas in relation to sea-surface parameters. American Association of Stratigraphic Palynologists Contribution Series 35:1-146.

Rollet, A.P. and Bouaziz, R. (1972). L'Analyse Thermique (Tome 2). Gauthier-Villars: Paris.

Satta,C.T.; Garcés,E.; Anglès,S.; Sechi,N.; Pulina.S.; Padedda, B.M.; Stacca, D. and Lugliè, A.(2014). Dinoflagellate Cyst Assemblages in Surface Sediments from Three Shallow Mediterranean Lagoons (Sardinia, North Western Mediterranean Sea). EstuariesCoast 37: 646-663

Simon, N.; Anne-Lise,C.; Elodie,F. and Rodolphe, L. (2009).Diversity and evolution of marine phytoplankton. C. R. Biol, 332(2-3):159-70.

Sournia, A. 1995. Red tide and toxic marine phytoplankton of the world ocean: an inquiry into biodiversity. In: "Harmful Marine Alagal Blooms.”, Lassus, P.; Arzul, G.; Erard, E.; 
Gentien P. \& Marcaillou, G. (Eds.). Lovoursier, Paris, pp. 103-112

Sournia,A.; Chrdtiennot-Dinet, M.J. and Ricard,M. (1991). Marine phytoplankton: how many species in the world ocean. J. Plankton Res. 13(5):1093-99.

Tesson, M. (1982). Quelques Caracteres De La Geochimie D’une Lagune Micro-Tidale: La Sebka Bou-Areg (Maroc). 106 Congrès National des Soctiétés Savantes, Perpignon Sciences, Fasc III: 181-194.

Yamaguchi, M.;Itakura,S.;Imai,I. and Ishida,Y. (1995). A rapid and precise technique for enumeration of resting cysts of Alexandrium spp.(Dinophyceae) in natural sediments. Phycologia, 34(3):207-14.

Zingone, A. and Enevoldsen,H.O. (2000). The diversity of harmful algal blooms: a challenge for science and management. Ocean Coast. Manage, 43(8-9):725-48.

Zonneveld, K.A.F. (1997a). Dinoflagellate cyst distribution in surface sediments from the Arabian Sea (northwestern Indian Ocean) in relation to temperature and salinity gradients in the upper water column ». Deep Sea Research Part II. Topical Studies in Oceanography 44(6-7):1411-43.

Zonneveld, K.A.F. (1997b). New species of organic walled dinoflagellate cysts from modern sediments of the Arabian Sea (Indian Ocean). Rev. Palaeobot. Palynol. 97(3-4):319-37.

Zonneveld, K.A.F. and Thomas, J. (1999). Bitectatodinium spongium (Zonneveld, 1997) Zonneveld et Jurkschat, comb. nov. from modern sediments and sediment trap samples of the Arabian Sea (northwestern Indian Ocean): taxonomy and ecological affinity. Rev. Palaeobot. Palynol. 106(3-4):153-69. 